\title{
Assessment of Vitamin D Level and Osteoporosis in Children with Sickle Cell Anemia
}

Mohamed Ahmed Badr' ${ }^{1}$, Amal Mohamed Abdel-Latef ${ }^{1}$, Nermin Raafat Abdel Fattah ${ }^{2}$, Asmaa Hassan Soliman Attia*1

Departments of ${ }^{1}$ Pediatrics and ${ }^{2}$ Medical Biochemistry, Faculty of Medicine, Zagazig University, Sharkia, Egypt

*Corresponding Author: Asmaa Hassan Soliman Attia, Mobile: (+20) 01007388138,

Email: eslamawahab@yahoo.com

\begin{abstract}
Background: Calcium and vitamin D are important for bone metabolism. The low calcium intake leads to a reduction in the ideal bone mass peak in children with sickle-cell anemia, which determines growth failure. There is little information on BMD in children with SCD and its association with 25(OH)D levels.

Objective: To evaluate the relation between Vitamin D level and bone mineral density in children with sickle cell disease.

Patients and Methods: This cross-sectional study was conducted over 6 months from February to August 2018. It included 30 patients (14 males and 16 females) with SCD who were following up regularly, at Pediatric Hematology outpatient clinics of Zagazig University Hospitals, their ages ranged from 6-18 years (mean $\pm \mathrm{SD}=12.3+3.84$ ).

Results: more than $3 / 4$ of the studied group has a deficient level of vitamin D (83.3\%). BMD of L1-L4 is normal in only $13.3 \%$ of the studied patients and BMD of total body is normal in the fifth of the studied patients $(20 \%)$. Correlation is non-significant between bone markers and Z-score of BMD, Z-score of BMD L1-L4, and vitamin D level among the studied sickle cell disease cases.

Conclusion: Vitamin D deficiency is a major nutritional health problem in patients with sickle cell disease. Emphasizes the need for vitamin D level screening for all SCD patients. Children with SCD have low BMD. There was no statistically significant correlation between vitamin D and (Z-score of BMD L1-L4, Z-score of BMD total body, Osteocalcin, and Beta cross lab) among the studied sickle cell disease cases.

Keywords: Sickle Cell Anemia, Vitamin D, Osteoporosis.
\end{abstract}

\section{INTRODUCTION}

Sickle cell disease is caused by a mutation resulting from an exchange of nitrogenous bases in the sixth codon of the beta-globulin hemoglobin gene, generating abnormal hemoglobin called hemoglobin $\mathrm{S}$ $(\mathrm{HbS})^{(\mathbf{1})}$. The manifestations of the sickle-cell disease are due to the presence of $\mathrm{HbS}$, of which molecules are organized into polymeric beams when deoxygenated and give the $\mathrm{RBC}$ an elongated and rigid conformation, called a "sickle-shaped red blood cell.

After the sickling process, the red blood cells begin to show changes in membrane proteins and increased expression of adhesion molecules that, consequently, lead to red blood cell adhesion to the endothelium. This process triggers an inflammatory phenomenon, activation of coagulation, hypoxia, ischemia, and local infarction, in addition to reduced RBC survival (2).

Calcium and vitamin D are important for bone metabolism, and the low calcium intake leads to a reduction in the ideal bone mass peak in children and adolescents with sickle-cell anemia, which determines growth failure. Vitamin D deficiency, in turn, is associated with increased respiratory infections, muscle weakness, and increased risk of falls and micro lesions ${ }^{(3)}$. Recent studies show that children with SCD frequently have severe vitamin D deficiency. Children with sickle cell disease (SCD) often develop bone complications manifested as vaso-occlusive bone pain crises, dactylitis, osteomyelitis, avascular necrosis, or vertebral deformity. In this population, the literature describes a decrease in BMD secondary to chronic anemia and bone marrow hyperplasia and associated with a higher risk of osteopenia and osteoporosis ${ }^{(4)}$.

Despite the higher risk of bone disease in this population, there is little information on BMD in children with SCD and its association with $25(\mathrm{OH}) \mathrm{D}$ levels and the risk of fractures ${ }^{(3)}$.

This work aimed to evaluate Vitamin D level and its relation to bone mineral density in children with sickle cell disease.

\section{PATIENTS AND METHODS}

This cross-sectional study was conducted over 6 months from February to August 2018. It Included 30 patients (14 males and 16 females) with SCD who were following up regularly, at Pediatric Hematology outpatient clinics of Zagazig University Hospitals, their ages ranged from 6-18 years (mean $\pm \mathrm{SD}=12.3+3.84)$. 


\section{Ethical Consideration:}

This study was ethically approved by the Institutional Reviewer Board (IRB) in the Faculty of Medicine, Zagazig University Hospital, and written parental consent from every case or their caregivers that participates in this research was taken.

\section{Inclusion Criteria:}

1. All children with SCD (HbSS, HbS $\beta+, \mathrm{HbAS}$ (trait), their ages ranged from 6-18 years.

2. Patients with sickle cell disease were in steady-state that is, no crises or acute illness within the preceding 6 weeks.

3. Both sets will be included in the study.

\section{Exclusion Criteria:}

1. We excluded children known to have conditions affecting growth or nutritional status.

2. We excluded children with chronic liver and kidney function abnormalities.

3. Children undergoing treatment with drugs that affect the skeleton and bone density.

4. Lack of consent (patient refusal to share in the study).

5. Other Hemoglobinopathy.

\section{All patients were subjected to the following:}

I. Complete history taking with special emphasis on age and sex. Initial clinical presentation of the disease (including pallor, vasoocclusive crises, bone pain, abdominal pain, chest pain).

The occurrence of vaso occlusive crises. Age of start and frequency of blood transfusion. Chelation therapy, age of start, type, and complications.

\section{Thorough clinical examination}

\section{Laboratory (Routine) investigations:}

CBC with Reticulocyte count. Hemoglobin Electrophoresis. Serum phosphorus. Serum calcium. Alkaline phosphatase.

\section{Specific investigations:}

\section{1) Vitamin D level}

Vitamin D deficiency should be defined as a $25(\mathrm{OH}) \mathrm{D}$ of $<20 \mathrm{ng} / \mathrm{ml}$. Vitamin D insufficiency is now recognized as a $25(\mathrm{OH}) \mathrm{D}$ of $21-29 \mathrm{ng} / \mathrm{ml}$. The preferred level for $25(\mathrm{OH}) \mathrm{D}$ is now recommended by many experts to be > $30 \mathrm{ng} / \mathrm{ml}$, or test different specimens. Bischoff-Ferrari HA, Giovannucci E, Willett WC, Dietrich T, Dawson-Hughes B.Vitamine $\mathrm{D}$ is measured using Enzyme Immune Essay technique.

\section{2) Parathormone hormone level.}

The PTH test measures the level of parathyroid hormone in the blood.PTH stands for parathyroid hormone, blood sample was taken to measure the amount of PTH in blood, normal values are 10 to 55 picograms per milliliter $(\mathrm{pg} / \mathrm{mL})$. Pagana KD, Pagana TJ. Fischbach FT, Dunning MB III, eds.

\section{3) Bone Markers including:}

\section{i. Osteocalcin level (Bone formation marker):}

It is Performed by taking the serum sample from all patients and use Human Osteocalcin ELISA Kit with Immunoradiometric assay (IRMA) technique, normal value is $9-42 \mathrm{ng} / \mathrm{m}$. University of Michigan Health Services. Pathology Handbook Review.

\section{ii. Beta Cross Lab Test (Bone resorption marker):}

The test was done using Human B-CTx ELIZA Kit with Immunoradiometric assay(IRMA). Normal values of B Cross Lab test: $35-950 \mathrm{pg} / \mathrm{mL}$.

\section{4) Dexa Scan.}

DEXA scan is a special type of X-ray that measures bone mineral density (BMD), DEXA stands for "dual-energy X-ray absorptiometry", This type of scan may also be called (DXA scan, bone density scan, bone densitometry scan).DEXA scans are often used to diagnose or assess someone's risk of osteoporosis, a condition that weakens bones and makes them more likely to break. We measured BMD at the posterioranterior spine, and not at the hip and the proximal femur due to the great variability of the latter areas during growth, adhering to the International Society for Clinical Densitometry (ISCD) recommendation for children.

The results were interpreted by an experienced DXA radiologist and expressed as Z-scores, that is the number of standard deviations (SDs) from the mean BMD of a child compared to other children of the same age, sex, and ethnicity, Z-scores below $-2 \mathrm{SD}$ were considered abnormal, low BMD or osteopenia was defined as a Z-score between-1 and -2 SDs, and a normal BMD as a Z-score above -1 SD. ${ }^{(5)}$.

\section{Statistical analysis}

The collected data were analyzed by computer using Statistical Package of Social Services version 24 (SPSS), Data were represented in tables and graphs, Continuous Quantitative variables e.g. age were expressed as the mean \pm SD \& median (range), and categorical qualitative variables were expressed as absolute frequencies (number)\& relative frequencies (percentage). Suitable statistical tests of significance were used after checked for normality. The results were considered statistically significant when the significant probability was less than $0.05(\mathrm{P}<0.05)$ and P-value $\geq 0.05$ was considered statistically insignificant (NS).

\section{RESULTS}

Table (1) shows that the mean age of the studied group is $12.3 \pm 3.84$ years old, with a range from 6 to 18 years old. More than half of the studied groups are male $(53.3 \%)$.

Table (2) shows that pallor is the initial clinical presentation of $96.7 \%$ of the studied children, mean age of pallor presentation is $22.17 \pm 21.75$ months, with a range from 5 months -7 years. Only $6.7 \%$ of them 
initially presented by Abdominal pain and joint pain.

Table (3) shows that SCA is the prevalent diagnosis in $60 \%$ of the studied group, S.C. B-thalassemia, and S.C. trait found in $(20 \% \& 20 \%)$ respectively.

Table (4) shows that the mean age of the start of transfusion among the studied group is $3.17 \pm 2.79$ years old, with a range from 5 months to 10 years old. about half of the studied group have blood transfusion regularly $(51.9 \%)$ every $1.96 \pm 2.87$ months, ranged from 2 weeks to 12 months.

Table (5) shows that the mean of serum Ca+ among the studied group is 9.12 \pm 7.3 , with a range from (6.110.5). And mean of Bone ALP among the studied group is $238 \pm 92.55$, with a range from (118-450).

Table (6) shows that the mean of Osteocalcin among the studied group is $35.48 \pm 47.22$, with a range from (3.04-163.34). And mean of Beta cross lab among the studied group is $854.95 \pm 468.28$, with a range from
(116.18-1523.17).

Table (7) shows that the mean of vitamin D level among the studied group is $16.22 \pm 5.75(\mathrm{ng} / \mathrm{ml})$, with a range from $(7.71-33.68)(\mathrm{ng} / \mathrm{ml})$. more than $3 / 4$ of the studied group has a deficient level of vitamin D $(83.3 \%)$.

Table (8) shows that BMD of L1-L4 is normal in only $13.3 \%$ of the studied patients and BMD of total body is normal in the fifth of the studied patients (20\%).

Table (9) shows that $88.9 \%$ of sickle cell anemia patients have vitamin d deficiency, while all patients with sickle cell anemia + thalassemia (100\%) have vitamin d deficiency, with a statistically significant difference $(\mathrm{p}<0.05)$.

Table (10) shows that correlation is non-significant between bone markers and Z-score of BMD, Z-score of BMD L1-L4, and vitamin D level among the studied sickle cell disease cases.

Table (1): Demographic data of the studied children $(\mathrm{N}=30)$.

\begin{tabular}{|l|c|c|}
\hline \multirow{2}{*}{\multicolumn{1}{|c|}{ Demographic data }} & \multicolumn{2}{c|}{ Studied children (N=30) } \\
\cline { 2 - 3 } & No. & \% \\
\hline Age (years) & \multicolumn{2}{|c|}{$12.3 \pm 3.84$} \\
\hline Mean \pm SD & \multicolumn{2}{|c|}{$12(6-18)$} \\
\hline Median (Range) & \multicolumn{2}{|c|}{} \\
\hline Sex & 16 & 53.3 \\
\hline Male & 14 & 46.7 \\
\hline Female & \multicolumn{2}{|c|}{} \\
\hline
\end{tabular}

Table (2): Initial clinical presentation among the studied sickle cell disease cases $(\mathrm{N}=30)$.

\begin{tabular}{|c|c|c|}
\hline \multirow{2}{*}{ Item } & \multicolumn{2}{|c|}{ Studied children $(\mathrm{N}=30)$} \\
\hline & No. & $\%$ \\
\hline Pallor & 29 & 96.7 \\
\hline Joint pain & 6 & 20.0 \\
\hline Abdominal pain and joint pain & 2 & 6.7 \\
\hline \multicolumn{3}{|c|}{ Age at pallor presentation (months) } \\
\hline - $\quad$ Mean \pm SD & \multicolumn{2}{|c|}{$22.17 \pm 21.75$} \\
\hline Median (Range) & \multicolumn{2}{|c|}{$12(5-84)$} \\
\hline
\end{tabular}

Table (3): Diagnosis among the studied sickle cell disease cases

\begin{tabular}{|l|c|c|}
\hline \multirow{2}{*}{\multicolumn{1}{|c|}{ Diagnosis }} & \multicolumn{2}{c|}{ Studied children $(\mathbf{N}=\mathbf{3 0})$} \\
\cline { 2 - 3 } & No. & $\mathbf{\%}$ \\
\hline S.C. A & 18 & 60.0 \\
\hline S.C. B-thalassemia & 6 & 20.0 \\
\hline S.C. trait & 6 & 20.0 \\
\hline
\end{tabular}


Table (4): Blood transfusion data among the studied sickle cell disease cases

\begin{tabular}{|l|c|c|}
\hline \multirow{2}{*}{\multicolumn{1}{|c|}{ Item }} & \multicolumn{2}{c|}{ Studied children } \\
\cline { 2 - 3 } & \multicolumn{2}{|c|}{ No. } \\
\hline Age of start (years) & \multicolumn{2}{|c|}{$3.17 \pm 2.79$} \\
\hline Mean \pm SD & \multicolumn{2}{|c|}{$2(5$ months-10 years) } \\
\hline Median (Range) & \multicolumn{2}{|c|}{$1(0.5-12)$} \\
\hline Frequency of transfusion (months) \\
\hline Mean \pm SD & \multicolumn{2}{|c|}{} \\
\hline Median (Range) & 48.1 \\
\hline The regularity of transfusion (N=27) \\
\hline Irregular & 13 & 51.9 \\
\hline Regular & 14 \\
\hline
\end{tabular}

Table (5): Serum Ca+, PH, ALP and ferritin among the studied sickle cell disease cases

\begin{tabular}{|l|c|}
\hline \multicolumn{1}{|c|}{ Item } & Studied children $(\mathbf{N}=30)$ \\
\hline - $\quad$ Mean \pm SD & $9.12 \pm 7.3$ \\
\hline serum Ph $\quad$ Median (Range) & $9.2(6.1-10.5)$ \\
\hline - $\quad$ Mean \pm SD & $4.32 \pm 0.63$ \\
\hline - $\quad$ Median (Range) & $4.1(3.3-5.4)$ \\
\hline Serum ALP & \\
\hline - Mean \pm SD & $238 \pm 92.55$ \\
\hline Serum ferritin & $250(118-450)$ \\
\hline - $\quad$ Mean \pm SD & $1619.7 \pm 1607.05$ \\
\hline - $\quad$ Median (Range) & $1099.15(15-6811)$ \\
\hline
\end{tabular}

Table (6): Bone markers among the studied sickle cell disease cases $(\mathrm{N}=30)$.

\begin{tabular}{|l|c|}
\hline \multicolumn{1}{|c|}{ Item } & Studied children $(\mathbf{N}=\mathbf{3 0})$ \\
\hline Osteocalcin .(ng/ml). & \\
\hline - & $35.48 \pm 47.22$ \\
\hline - Mean \pm SD & $17.46(3.04-163.34)$ \\
\hline Beta cross lab(pg/ml). & $854.95 \pm 468.28$ \\
\hline - Mean \pm SD & $991.74(116.18-1523.17)$ \\
\hline - Median (Range) & \\
\hline
\end{tabular}

Table (7): Vitamin D level and status and Parathyroid Hormone among the studied sickle cell disease cases (N=30).

\begin{tabular}{|c|c|c|}
\hline \multirow[t]{2}{*}{ Item } & \multicolumn{2}{|c|}{ Studied patients $(\mathrm{N}=30)$} \\
\hline & No & $\%$ \\
\hline \multicolumn{3}{|l|}{ Vitamin D level(ng/ml) } \\
\hline Mean $\pm \mathrm{SD}$ & \multicolumn{2}{|c|}{$16.22 \pm 5.75$} \\
\hline Median (Range) & \multicolumn{2}{|c|}{$15.4(7.71-33.68)$} \\
\hline \multicolumn{3}{|l|}{ Vitamin D status } \\
\hline Deficiency (0-20) & 25 & 83.3 \\
\hline Normal ref range (20-100) & 5 & 16.7 \\
\hline \multicolumn{3}{|c|}{ Parathyroid Hormone(pg/ml). } \\
\hline Mean \pm SD & \multicolumn{2}{|c|}{$41.14 \pm 9.58$} \\
\hline Median (Range) & \multicolumn{2}{|c|}{$45.1(18.4-55)$} \\
\hline
\end{tabular}


Table (8): $\mathrm{Z}$ score of BMD among the studied sickle cell disease cases $(\mathrm{N}=30)$.

\begin{tabular}{|c|c|c|c|c|}
\hline \multirow{2}{*}{ Item } & \multicolumn{2}{|c|}{ BMD(N=30) } & \multicolumn{2}{|c|}{ Z-score } \\
\hline & No & $\%$ & Mean \pm SD & Median (Range) \\
\hline \multicolumn{5}{|l|}{ L1-L4 } \\
\hline Normal & 4 & 13.3 & \multirow[t]{2}{*}{$-2.33 \pm 1.42$} & \multirow[t]{2}{*}{$-1.8\left(-4.9 \_0.2\right)$} \\
\hline low & 26 & 86.7 & & \\
\hline \multicolumn{5}{|l|}{ Total body } \\
\hline Normal & 6 & 20.0 & \multirow[t]{2}{*}{$-1.45 \pm 0.89$} & \multirow[t]{2}{*}{$-1.6\left(-3.6 \_0.2\right)$} \\
\hline low & 24 & 80.0 & & \\
\hline
\end{tabular}

Table (9): Relation between type of sickle cell disease and vitamin D status among studied sickle cell disease cases

\begin{tabular}{|c|c|c|c|c|c|c|c|c|}
\hline \multirow{3}{*}{ Variable } & \multicolumn{6}{|c|}{ Diagnosis } & \multirow{3}{*}{$\begin{array}{l}\text { Chi- } \\
\text { square } \\
\text { test }\end{array}$} & \multirow{3}{*}{ P-value } \\
\hline & \multicolumn{2}{|c|}{$\begin{array}{c}\text { SCA } \\
\mathbf{N}=(18)\end{array}$} & \multicolumn{2}{|c|}{$\begin{array}{c}\mathrm{SC} \\
\text { B-thalassemia } \\
\mathrm{N}=(\mathbf{6}) \\
\end{array}$} & \multicolumn{2}{|c|}{$\begin{array}{c}S C \text { trait } \\
N=(6)\end{array}$} & & \\
\hline & No & $\%$ & No & $\%$ & No & $\%$ & & \\
\hline \multicolumn{9}{|l|}{ Vitamin D status } \\
\hline Deficiency & 16 & 88.9 & 6 & 100.0 & 3 & 50.0 & \multirow{2}{*}{6.400} & \multirow{2}{*}{$\begin{array}{l}0.041^{*} \\
\quad(\mathrm{~S})\end{array}$} \\
\hline Normal ref range & 2 & 11.1 & 0 & 0.0 & 3 & 50.0 & & \\
\hline
\end{tabular}

Table (10): Correlation between bone markers and Z-score of BMD and vitamin d among the studied sickle cell disease cases

\begin{tabular}{|l|c|c|}
\hline \multicolumn{1}{|c|}{ Item } & \multicolumn{2}{|c|}{ Vitamin D } \\
\cline { 2 - 3 } \multicolumn{1}{|c|}{ Z-scoreof BMD L1-L4 } & -0.076 & p- value \\
\hline Z-score of BMD total body & 0.040 & 0.697 \\
\hline Osteocalcin & 0.116 & 0.832 \\
\hline Beta cross lab & -0.030 & 0.541 \\
\hline
\end{tabular}

\section{DISCUSSION}

This study demonstrated that $53.3 \%$ of the studied children are male and $46.7 \%$ are female. This agrees with ${ }^{(6)}$ who revealed that $\mathrm{HbS}$ in $\mathrm{SCD}$ is transmitted as an autosomal codominant characteristic. The male-to-female ratio is $1: 1$. No sex predilection exists, since sickle cell anemia is not an X-linked disease.

On the contrary, Lal et al. ${ }^{(7)}$ show a higher female-to-male ratio where 25 children with sickle cell anemia (12 male and 13 female) with a median age of 12.8 years (10.2 -19.8 years).

Our study showed that the initial clinical presentation was pallor. pallor is the initial clinical presentation of $96.7 \%$ of the studied children, mean age of pallor presentation is $22.17 \pm 21.75$ months, with a range from 5 months -7 years. Only $6.7 \%$ of them initially presented by Abdominal pain and joint pain.

da Silva Filho et al. ${ }^{\left({ }^{(8)}\right.}$ described the clinical events in a retrospective study in patients with SCD under 6 years and reported painful events and acute chest syndrome to be more frequent in under 3years old children, $94 \%$ of children had at least one episode.
Our study shows that $90 \%$ of patients received a blood transfusion, about half of the studied group have blood transfusion regularly (51.9\%) every $1.96 \pm$ 2.87 months, ranged from 2 weeks to 12 months while $48.1 \%$ of them received transfusion irregularly.

The increased use of transfusions may ultimately be balanced by hydroxyurea and other newer therapies developed as the complex pathophysiology of SCD is better understood; however, red cell transfusion is currently the most studied and accepted therapy for most acute and many chronic complications of SCD. Physicians caring for patients with sickle cell disease should be aware of the unique complications and transfusion requirements in this population ${ }^{(9)}$.

This is in agreement with Enninful-Eghan $\boldsymbol{e t}$ $\boldsymbol{a l}^{\left({ }^{(10)}\right)}$ that found most children (95\%) initially received simple transfusions.

The increased use of transfusions may ultimately be balanced by hydroxyurea and other newer therapies developed as the complex pathophysiology of SCD is better understood; however, red cell transfusion is considered the most studied and accepted therapy for most acute and many chronic complications of SCD. Physicians caring for patients with sickle cell disease 
should be aware of the unique complications and transfusion requirements in this population (11).

This is consistent with Hagag et al. ${ }^{(12)}$ who revealed that most of the studied patients received blood transfusion every more than 4 weeks.

This study showed that more than threequarters of the studied group has a deficient level of vitamin D (83.3\%).

This agrees with Hamdy $\boldsymbol{e t} \boldsymbol{a l} .{ }^{(13)}$ who aimed to detect the prevalence of vitamin D deficiency among Egyptian patients with SCD and to associate it with the clinical course of the disease. They revealed that vitamin D was deficient in $60 \%$ of SCD compared to $26.7 \%$ of controls. Severe VDD was significantly higher in SCD patients than controls.

This agrees also with AlJama et al. ${ }^{(14)}$ who aimed to estimate the 25-hydroxyvitamin $\mathrm{D}(25(\mathrm{OH}) \mathrm{D})$ level and the frequency of VDD and insufficiency among SCD patients. They showed a high frequency of suboptimal $25(\mathrm{OH}) \mathrm{D}$ (insufficiency and deficiency) in SCD patients, reaching $82 \%$, which is comparable to other studies where the frequency reached up to $96 \%$. $^{(15)}$

We suggest that this deficiency resulted from several factors. Our district, Zagazig, is sunny. However, some factors may reduce the exposure time to the sun, the area exposed, and depth of penetration. Immobilization due to arthropathy and frequent hospitalizations also may result in a degree of sun deprivation. Also, rapid changes in calcium metabolism caused by immobilization and inactivity can decrease vitamin D levels.

The main source of vitamin $D$ is synthesis in skin tissue in response to exposure to ultraviolet $B$ light $(290-320 \mathrm{~nm})$. The factors of changing sunlight exposure time, area, and light penetration will affect the amount of vitamin D synthesis in the skin. Some of the variable factors involved are the degree of skin exposure, clothing, latitude, season, time of day, use of sunscreen, skin pigmentation, and racial origin. Food sources of vitamin D are less available and include fatty fish, egg yolks, and fish liver oils. Prophylactic vitamin $\mathrm{D}$ supplementation is an option in risky climates, regions, and subgroups ${ }^{(\mathbf{1 6}) .}$

Careful assessment and effective management of risk factors concomitant with bone loss and secondary causes of osteoporosis are recommended. The attainment of optimum calcium intake and adequate vitamin $\mathrm{D}$ is significant ${ }^{\mathbf{( 1 7 )}}$.

This study showed that the mean of serum $\mathrm{Ca}+$ among the studied group is $9.12 \pm 7.3$, with a range from (6.1-10.5), the mean of serum $\mathrm{Ph}$ among the studied group is 4.3 \pm .6 , with a range from (3.3-5.4) and mean of Bone ALP among the studied group is $238 \pm 92.55$, with a range from (118-450).

Van der Dijs et al. ${ }^{(18)}$ observed that, when compared to healthy controls, patients with sickle-cell anemia had lower serum calcium concentrations. These levels, however, were not below reference values. In the same study, there was no difference between the groups regarding the phosphate, parathormone, and vitamin D levels.

This study showed that the mean of Osteocalcin among the studied group is $35.48 \pm 47.22$, with a range from (3.04-163.34).

Chapelon et al. ${ }^{(19)}$ found that the mean of Osteocalcin among the studied SCD group is $45.3 \pm$ 22.6, with a range from (11-106).

Osteocalcin levels are higher during childhood, and their peak occurs during puberty. ${ }^{(20)}$ This fact could explain the inverse correlation, as the older the age, the higher the production of osteocalcin.

This study showed that BMD of L1-L4 is low in $86.7 \%$ of the studied patients and BMD of total body is low in four-fifth of the studied patients (80\%).

This agrees with Gupta et al. (21) who found that Low bone mineral density (BMD) is common in sickle cell disease (SCD) patients. Miller et al. (22) found that the prevalence of low BMD was ( $66 \%$ of patients with SCD) in the lumbar spine.

This study showed that, among 30 children with sickle cell disease patients, 18 cases had SCA, 6 cases had sickle cell anemia + thalassemia, and patients with SC trait was 6 cases. SCA( HbSS ) is the prevalent diagnosis in $60 \%$ of the studied group, S.C. Bthalassemia $(\mathrm{HbS} \beta+)$ and S.C. trait ( $\mathrm{HbAS})$ found in $(20 \% \& 20 \%)$ respectively.

Leite et al. ${ }^{(23)}$ showed that the most prevalent genotype in their study was $\mathrm{Hb}$ SS (74.4\%).

In another study done by Asbeutah et al. ${ }^{(24)}$, the study consisted of 43 patients with SCD; $48.8 \%$ were SS, $44.2 \%$ were SB0 and $7 \%$ were $\mathrm{Hb}$ AS (trait).

Tantawy et al. ${ }^{(25)}$ reported that $32 / 60$ patients (53\%) had HbSB (20 had $\mathrm{HbS} \beta+$ and 12 had $\mathrm{HbS} \beta 0$ ), and 28/60 patients (47\%) had HbSS disease. Also, a higher percentage of homozygous sickle cell anemia compared to other genotypes was reported in many studies.

Chapelon et al. ${ }^{(19)}$ who aimed to assess the prevalence in children with sickle cell disease of low bone mineral density (BMD), a feature found in children (45 SS, 4 SC, 4 Sb-thalassemia).

This study showed that $88.9 \%$ of sickle cell anemia patients have vitamin d deficiency, while all patients with sickle cell anemia + thalassemia (100\%) have vitamin d deficiency and patients with SC trait (50\%) have vitamin d deficiency with a statistically significant difference $(\mathrm{p}<0.05)$.

This study showed that there was no statistically significant correlation between vitamin $\mathrm{D}$ and (Z-score of BMD L1-L4, Z-score of BMD total body, Osteocalcin, and Beta cross lab) among the studied sickle cell disease cases. Chapelon et al. ${ }^{(19)}$ found that BMD was not correlated with vitamin D status, osteocalcin, or bone resorption markers. 
In sickle cell anemia, the bone can be affected by microinfarctions, osteopenia, osteonecrosis, osteoporosis, and osteomyelitis ${ }^{(26)}$. Risk factors for the occurrence of osteopenia in sickle-cell disease include delayed puberty and the low competence of bone mass metabolism peak, microinfarctions resulting from vasoocclusive events, chronic pain with immobilization, and of the efficiency of calcium, vitamin D, and other nutrients ${ }^{(7)}$.

\section{CONCLUSION}

This study concluded that Vitamin D deficiency is a major nutritional health problem in patients with sickle cell disease. Emphasizes the need for vitamin D level screening for all SCD patients. Treatment of vitamin D hypovitaminosis and maintenance with vitamin $\mathrm{D}$ doses meeting the daily requirements should be ensured. Children with SCD have low BMD. There was no statistically significant correlation between vitamin D and (Z-score of BMD L1-L4, Z-score of BMD total body, Osteocalcin, and Beta cross lab) among the studied sickle cell disease cases.

Sources of Support: No funding - No grants.

Conflict of Interest: No conflict of interest

\section{REFERENCES}

1. Zago M (2002): Considerações gerais sobre as doenças falciforme. Manual de diagnóstico e tratamento das doenças falciformes.Agência Nacional de Vigilância Sanitária, org. Ministério da Saúde. Brasília, Pp.9-11.

2. Zago M, Pinto A (2007): The path physiology of sickle cell disease: from the genetic mutation to multiorgan dysfunction. Rev Bras Hematol Hemoter., 29:2007-14.

3. Ferrari S, Bianchi M, Eisman J et al. (2012): Osteoporosis in young adults: path physiology, diagnosis, and management. Committee of Scientific Advisors Working Group on Osteoporosis Path physiology. Osteopor Int., 23:2735---48.

4. Ganguly A, Boswell W, Aniq H (2011): Musculoskeletal manifestation of sickle cell anemia; a pictorial review. https://www. hindawi.com/journals/ anemia/2011/794283/

5. Bianchi M (2007): Osteoporosis in children and adolescents. Bone, 41:486---95.

6. Côbo V, Chapadeiro C, Ribeiro J et al. (2013): Sexuality and sickle cell anemia. Revista brasileira de hematologia e hemoterapia, 35(2): 89-93.

7. Lal A, Fung E, Pakbaz $Z$ et al. (2006): Bone mineral density in children with sickle cell anemia. Pediatr Blood Cancer, 47:901-906.

8. da Silva Filho I, Ribeiro G, Moura P et al. (2012): Sickle cell disease: acute clinical manifestations in early childhood and molecular characteristics in a group of children in Rio de Janeiro. Revista Brasileira de Hematologia e Hemoterapia, 34(3): 196-201.

9. Wanko S, Telen M (2005): Transfusion management in sickle cell disease. Hematol Oncol Clin North Am., 19:8038.

10.Enninful-Eghan H, Moore R, Ichord $R$ et al. (2010): Transcranial doppler ultrasonography and prophylactic transfusion program are effective in preventing overt stroke in children with sickle cell disease. Journal of Pediatrics, 157(3):479-84.

11.Wahl S, Quirolo K (2009): Current issues in blood transfusion for sickle cell disease. Curr Opin Pediatr., 21(1):15-21.

12.Hagag A, El-Farargy S, Abo El-Enein A (2015): Study of Adrenal Functions using ACTH stimulation test in Egyptian children with Sickle Cell Anemia: Correlation with Iron Overload. International Journal of Hematology-Oncology and Stem Cell Research, 9(2): 60-6.

13. Hamdy M, Salama N, Maher G et al. (2018): Vitamin D and Nonskeletal Complications among Egyptian Sickle Cell Disease Patients. Advances in Hematology, doi: $10.1155 / 2018 / 3867283$

14. AlJama A, AlKhalifah M, Al-Dabbous I et al. (2018): Vitamin D deficiency in sickle cell disease patients in the Eastern Province of Saudi Arabia. Annals of Saudi Medicine, 38(2): 130-136.

15. Nolan V, Nottage K, Cole E et al. (2015): Prevalence of vitamin D deficiency in sickle cell disease: a systematic review. PLoS One, 10(3):0119908.

16.Ginde A, Liu M, Camargo C (2009): Demographic differences and trends of vitamin D insufficiency in the US population. Arch Intern Med., 169:626-632.

17. Anagnostis P, Karras S, Paschou S et al. (2015): Haemophilia A and B as a cause for secondary osteoporosis and increased fracture risk. Blood Coagul Fibrinolysis, 26:599-603.

18. Van der Dijs F, van der Klis F, Muskiet F et al. (1997): Serum calcium and vitamin D status of patients with sickle cell disease in Curac sao. Ann Clin Biochem., 34:170-1722.

19. Chapelon E, Garabédian M, Brousse V et al. (2009): Osteopenia and vitamin D deficiency in children with sickle cell disease. Arch Pediatr., 16(6):619-21.

20.Bringhurst F, Demay M, Kronenberg H et al. (2003): Hormones and disorders of mineral metabolism. In: Larsen PR, Kronenberg HM, Melmed S, et al. Williams textbook of endocrinology. Philadelphia: W.B. Saunders; Pp. 13181320.

21. Gupta R, Marouf R, Adekile A (2010): Pattern of bone mineral density in sickle cell disease patients with the highHb F phenotype. Acta Haematol., 123(1):64-70.

22. Miller R, Segal J, Ashar B et al. (2006): High prevalence and correlates of low bone mineral density in young adults with sickle cell disease. Am J Hematol., 81(4):236-41.

23. Leite A, de Oliveira $R$, de Moura $P$ et al. (2012): Abnormal transcranial Döppler ultrasonography in children with sickle cell disease. Revista Brasileira de Hematologia e hemoterapia, 34(4), 307-10.

24. Asbeutah A, Gupta R, Al-Saeid O et al. (2013): Transcranial Doppler and brain MRI in children with sickle cell disease and high hemoglobin F levels. Pediatric Blood \& Cancer, 61(1): 25-28.

25. Tantawy A, Andrawes N, Adly A et al. (2013): Retinal changes in children and adolescents with sickle cell disease attending a pediatric hospital in Cairo, Egypt: risk factors and relation to ophthalmic and cerebral blood flow. Transactions of the Royal Society of Tropical Medicine and Hygiene, 107(4), 205-211.

26. Sarrai M, Duroseau H, D.Áugustine J et al. (2007): Bone mass density in adults with sickle cell disease. $\mathrm{Br} \mathrm{J}$ Haematol., 136:666-672. 